\title{
陸域負荷の異なる中国地方一級河川の河川生態 環境評価 \\ RIVER ECOSYSTEM ASSESMENT OF FIRST CLASS RIVERS WITH DIFFERENT LAND LOAD IN CHUGOKU DISTRICT
}

\author{
赤松良久 $1 \cdot$ 高村紀彰 2 ・馬場祐貴 3 \\ Yoshihisa AKAMATSU, Yoshiaki TAKAMURA and Yuki BABA \\ 1正会員 博 (工) 山口大学大学院准教授 理工学研究科社会建設工学専攻 \\ （干755-8611 山口県宇部市常盤台2-16-1） \\ 2学生会員 学(工) 山口大学大学院生 理工学研究科社会建設工学専攻 \\ （干755-8611 山口県宇部市常盤台2-16-1） \\ 3非会員 学(工) 山口大学 工学部社会建設工学科（干755-8611 山口県宇部市常盤台2-16-1）
}

\begin{abstract}
The field observations on water quality and amount of organism: detritus, attached alge and benthic animal were conducted at several points in Saba River and Ashida River of Chugoku District, which have a different characteristic of land load. An ecosystem assessment method based on exergy efficiency was applied to these rivers, and were compared with that using water quality and biodiversity of benthic animal. The result shows that the exergy efficiency can clarify the difference of the soundness of river ecosystem between the observation points of Saba River and Ashida River, and correlates with the biodiversity of benthic animal, which is not clearly related to the water quality.
\end{abstract}

Key Words : exergy efficiency, river ecosystem, assessment method, Saba River, Asida River

\section{1. はじめに}

これまで，河川環境の評価は，主にBODに代表される 水質調査によって行われてきた．今日，日本全国の9割 の一級河川においてBOD值が環境基準を満たしており, 有機污濁という観点からの河川の水質環境の回復は著し い. しかし，栄養塩という観点からみると，全リン（TP）は6割以上の河川で改善傾向にあるものの，全窒素

（T-N）は近年悪化傾向にある河川も4割近くある ${ }^{1)}$ 。ま た，河川生態系の上位に位置するアユに着目してみると， アユの現存量は水質の回復とは逆に2000年以降急激に減 少している2).したがって, 河川の栄養塩環境や生態系 という観点から，河川生態環境を評価する必要があると 考えられる.

河川生態環境を評価する方法は魚類，底生動物，付着 藻類などの生物, 生物種, 生物群落を指標とする方法と 生物の生息適性を指標とする方法に大別される，近年の 生物多様性一の注目の高まりから, 生物種や生物群落を 指標とする方法が河川生態環境を評価するには最適であ
ると考えられる. しかし，種多様性を環境評価に用いる のは適切ではないとの見方もある ${ }^{3)}$. 後者は PHABSIM(Physical Habitat Model ) )などに代表される特定 種の生息環境の評価を行う生息場評価モデルである。こ れらのモデルは基本的には物理環境場によって評価され るために生態系の仕組みや生物多様性が考慮されていな い.

以上のような問題点から，我が国では統一的な河川生 態環境評価はまだ行われていない，一方で，海外では魚 類や底生動物の生物種や群集からランク付け寸る方法や それらと物理環境を指標とする方法を組み合わせた方法 なども導入されており，日本においても小出水ら5によ る実施事例がある.

これに対して，赤松ら $\left.{ }^{6}\right)$ は生態系の健全性が生態系内 のエクセルギー効率によって代表されるという考えに基 づいて，新たな河川生態環境評価法を提案している. 本研究では陸域負荷の異なる中国地方一級河川を対象と して, エクセルギー効率と従来の水質や生物による環境 評価を行い，エクセルギー効率に基づく新たな河川生態 環境評価法の有用性を検討した。 

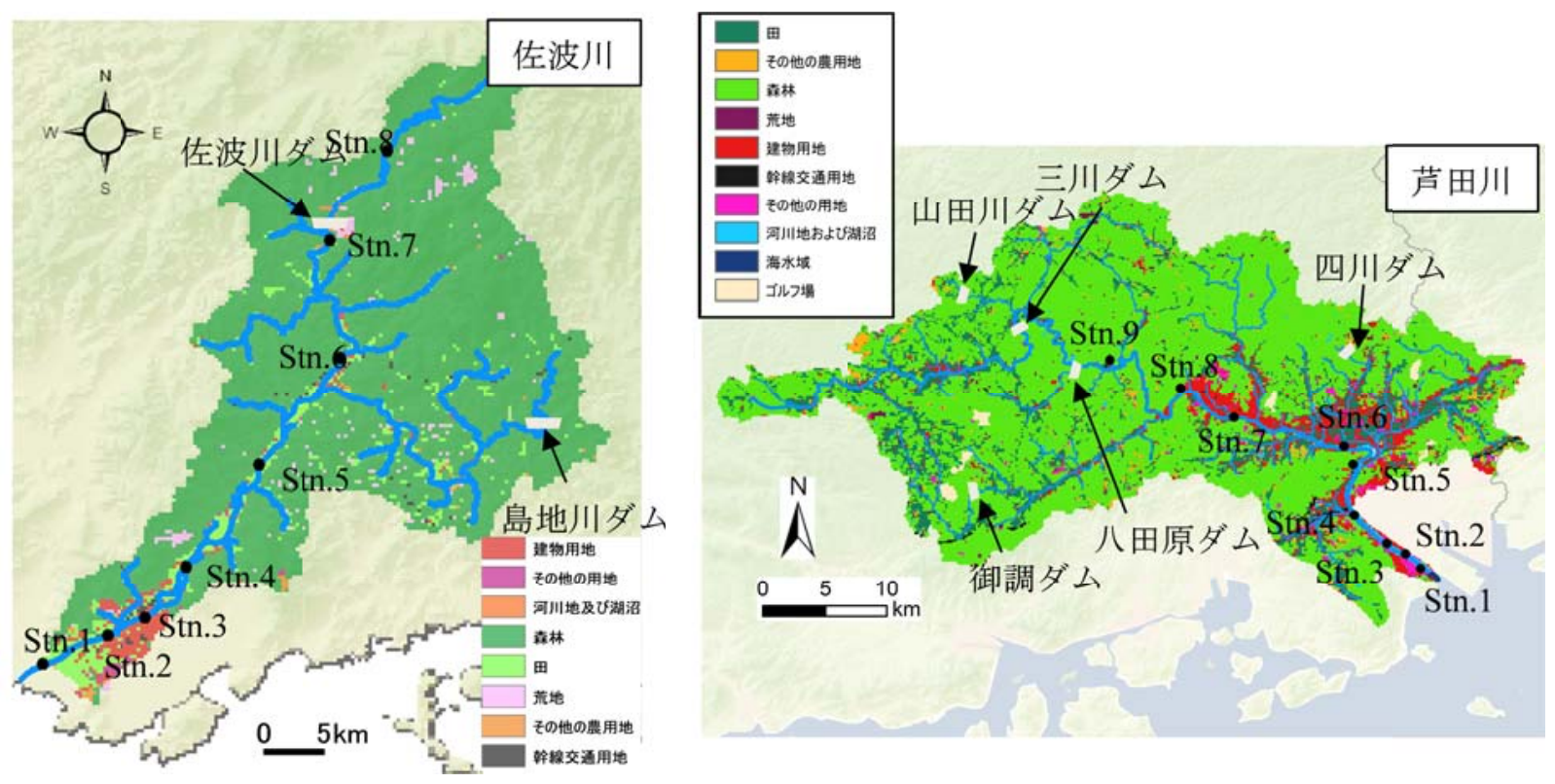

図-1 研究対象域
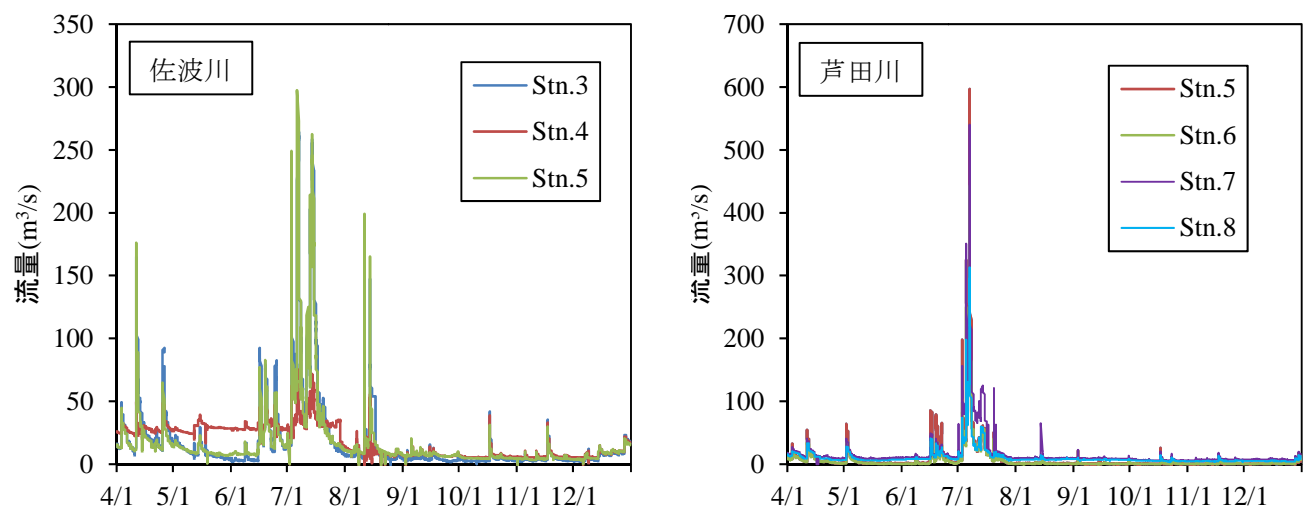

図-2 佐波川Stn. 3〜5および芦田川Stn. 5 8の流量変化

\section{2. 佐波川および芦田川における現地観測}

\section{(1) 観測概要}

現地観測は，中国地方の一級河川である山口県佐波川 および広島県芦田川を対象として行った（図-1）。佐波 川は幹川流路延長 $56 \mathrm{~km}$ ，流域面積 $446 \mathrm{~km}^{2}$ であり，佐波 川水系には本流の上流に佐波川ダム, 支流の島地川の上 流に島地川ダムが存在する. 芦田川は幹川流路延長 $86 \mathrm{~km}$, 流域面積 $860 \mathrm{~km}^{2}$ であり, 芦田川水系では本流に八田原ダ ム，三川ダムが存在し，支流にも複数のダムが存在して いる．佐波川においては河口近くに市街地が広がるもの の, 中上流では森林や水田が広がっている. それに対し て，芦田川では中流のStn.8から河口域まで市街地が続い ている.したがって，両河川の陸域からの污濁負荷は大 きく異なる.

佐波川のStn.2〜 5の様子を写真-1に示す.Stn.2は堰の
直下に当たる場所であり，河口に近い淡水域であるため アユの産卵場となっている. そのため, 人為的に河床の 撹乱が行われている. Stn.3は新橋の上流に位置し，高水 敷は樹林化が進んでいる.Stn.4では上流の金波堰が2007 年に撤去され，河床の変動が活発な状態にある.Stn.5は 大砶が多く存在していた。また，芦田川のStn.4〜8の様 子を写真-2に示す. Stn.7, 8では大硯が存在し, 底生生 物等が生息可能な空間となっているものの，Stn.4〜6は 細碩成分が多く夏季にはオオカナダモ等の沈水植物の繁 茂も見られた。

まず，佐波川本流の上流から下流までのStn.1〜8およ び芦田川の上流から下流までのStn.1〜9を対象として水 質調查を実施した。水質に関几ては栄養塩濃度（T-N, T$\left.\mathrm{P}, \mathrm{NO}_{3}-\mathrm{N}, \mathrm{NO}_{2}-\mathrm{N}, \mathrm{NH}_{4}-\mathrm{N}, \mathrm{PO}_{4}-\mathrm{P}\right)$ ，の計測を行った.

次に，佐波川のStn.2〜 5および芦田川のStn.4〜8の各地 点の平瀬で $1 \mathrm{~m} \times 1 \mathrm{~m}$ のコドラード内の河床に堆積する有機 物, 底生動物, 付着藻類のサシプリングを行った。佐波 川では2012年4月18日，5月30日，7月25日，9月11日，11 


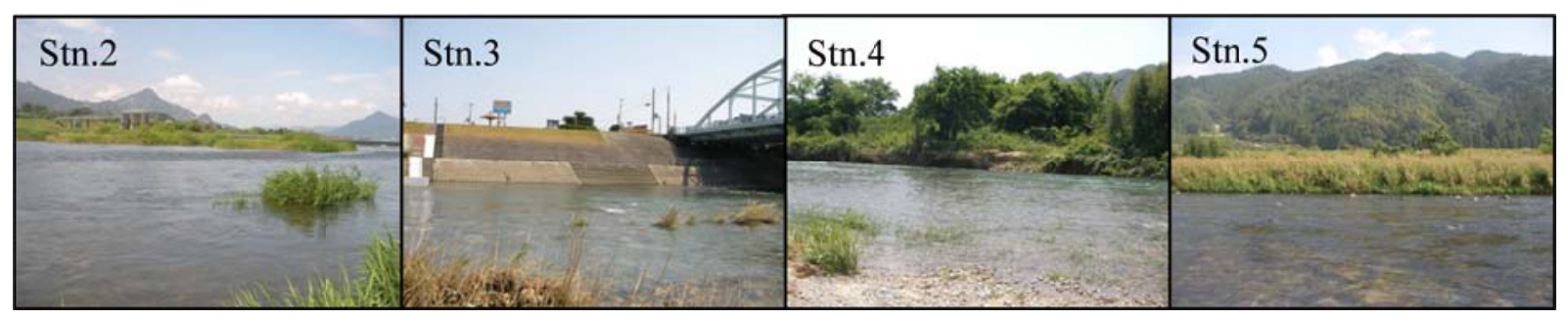

写真-1 佐波川のStn. 2 5 の状況

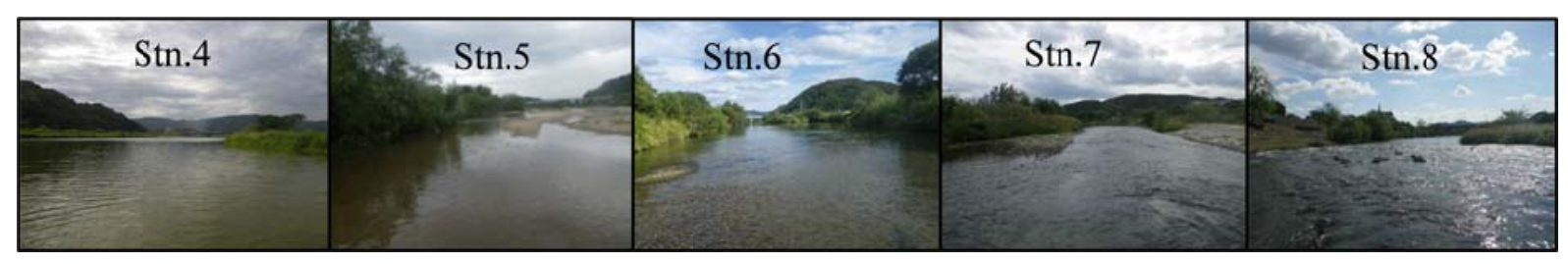

写真-2＼cjkstart芦田川のStn. 4 8 の状況

(a) $\mathrm{NO}_{3}-\mathrm{N}+\mathrm{NO}_{2}-\mathrm{N}$

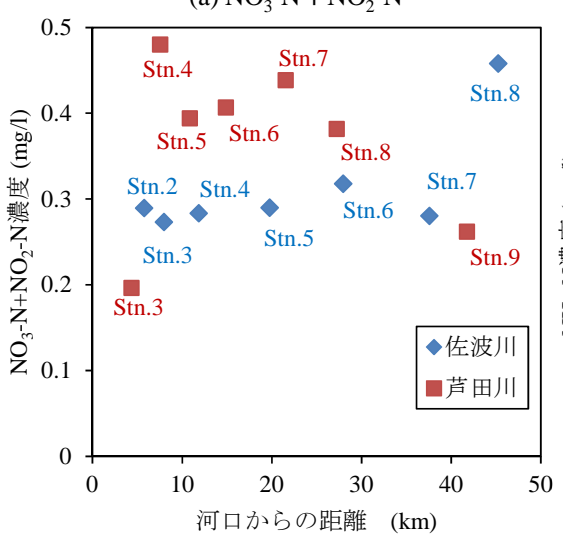

(b) $\mathrm{NH}_{4}-\mathrm{N}$

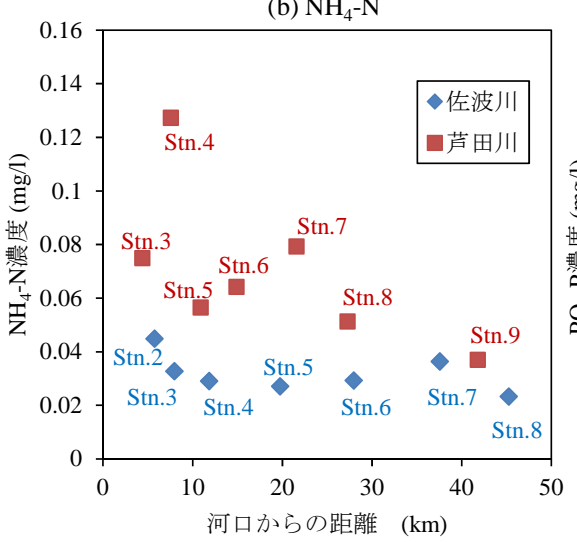

(c) $\mathrm{PO}_{4}-\mathrm{P}$

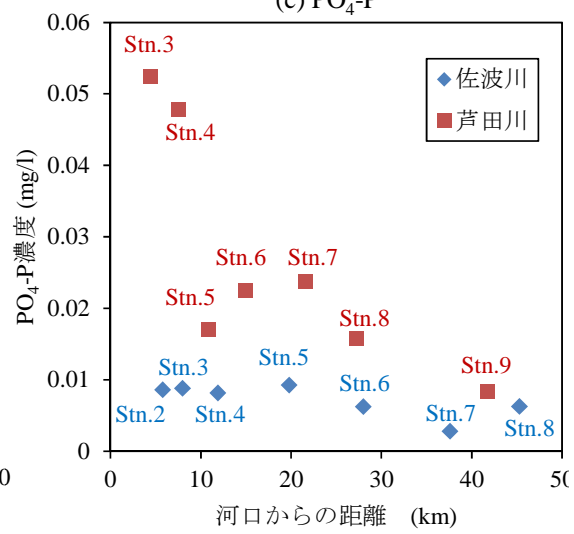

図-3 佐波川および芦田川の (a) $\mathrm{NO}_{3}-\mathrm{N}+\mathrm{NO}_{2}-\mathrm{N}$ (b) $\mathrm{NH}_{4}-\mathrm{N}$ (c) $\mathrm{PO}_{4}-\mathrm{P}$ 濃度の縱断分布

月5日，12月21日の計6回，芦田川では2012年6月13日，7 月19日，8月28日，10月12日，12月3日の計5回行った. 有機物と底生動物はコドラード内の河床を擋乱し，下流

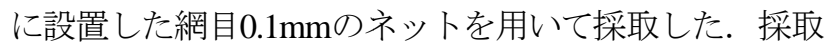
したサンプルの乾燥質量を測定した後に，強熱減量を測 定した. 付着藻類はコドラート内の粒径 $50 \mathrm{~mm}$ 以上のす ベての砅からブラシではがし取り, WhatmanGF/F規格の フィルターを利用して濾過した後に乾燥質量を測定した 後に, 強熱減量を測定した. 同時に流速や水深の計測を 行った. また，同地点には自己記録式の水温計を設置し， 水温の連続モニタリングを行った.

観測期間中の佐波川Stn.3〜 5および芦田川Stn.5〜8の流 量変化を図-2に示寸 (流量データは国土交通省山口河川 国道事務所および福山河川国道事務所にご提供頂いた）。 芦田川は佐波川に比べて, 出水の頻度が少ないことがわ かる.これは芦田川では本流および支流に多くのダムが 存在するためであると考えられる.

\section{（2）現地観測結果}

図-3 (a) に観測期間中の平均の $\mathrm{NO}_{3}-\mathrm{N}+\mathrm{NO}_{2}-\mathrm{N}$ 濃度の縦 断分布を示寸．なお，塩水の影響を受ける佐波川のStn.1 および芦田川のStn.1, 2は割愛した. 佐波川においてはダ ムの上流のStn.8では高く, ダム下流のStn.7から河口まで はほとんど濃度に変化がないことがわかる，芦田川では 河口に近いStn.3 で低く, 上流のStn.9から周辺に市街地 を有する下流地点に行くにつれて濃度が高くなっている。 全体的には芦田川の濃度が佐波川に比べて高い。また,

図-3 (b), (c) に観測期間中の平均 $の \mathrm{NH}_{4}-\mathrm{N}, \mathrm{PO}_{4}-\mathrm{P}$ 濃度の 縦断分布を示寸．佐波川においては河口に近づくにつれ て濃度が高くなる傾向があるものの, 全域にわたって濃 度は低い. 芦田川では河口に近づくにつれて濃度が高く なる傾向が顕著である. また, 芦田川のStn.4では $\mathrm{NO}_{3}-\mathrm{N}$ $+\mathrm{NO}_{2}-\mathrm{N}, \quad \mathrm{NH}_{4}-\mathrm{N}, \mathrm{PO}_{4}-\mathrm{P}$ 濃度吕高く, その他の地点に比 べて特に水質環境が悪いことがわかる.

図-4に佐波川のStn.2〜5および芦田川のStn.4〜8の有機 物量, 底生動物量, 付着藻類量の変化を示す. 佐波川で 

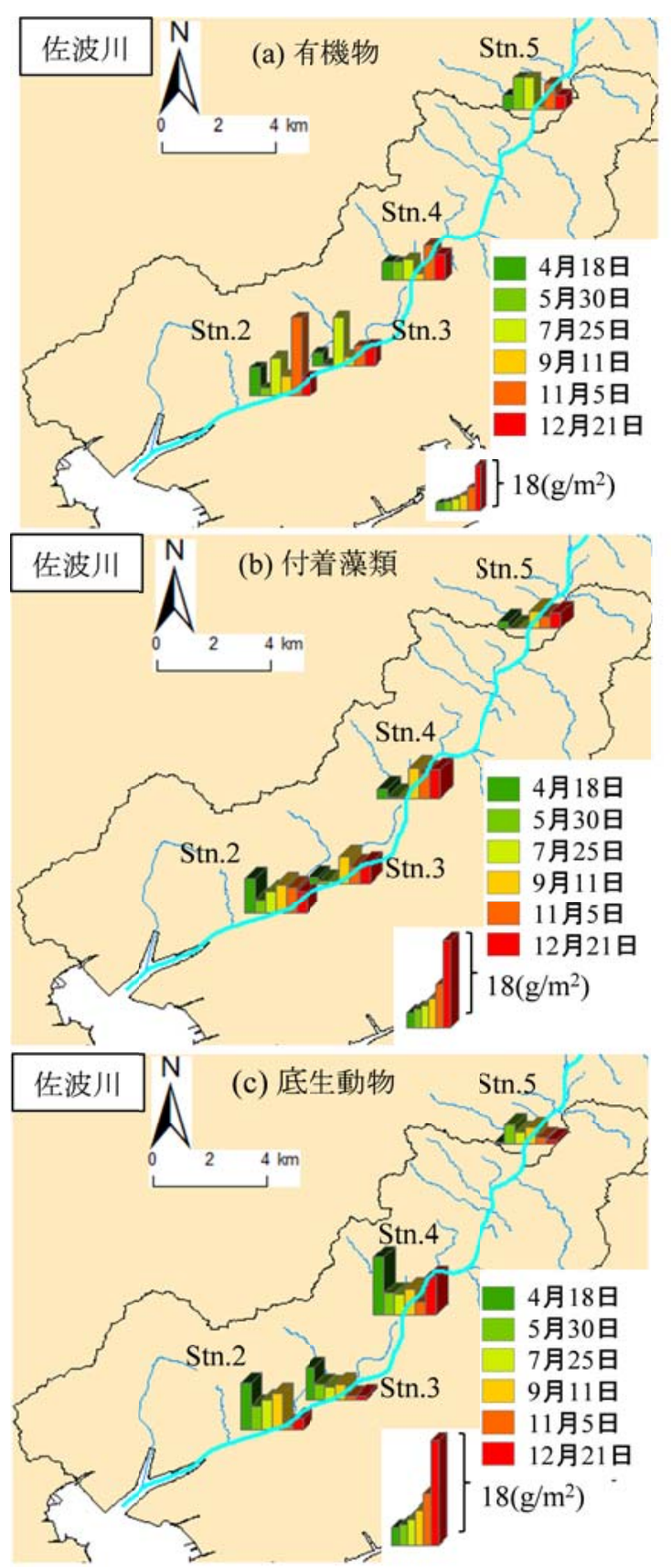
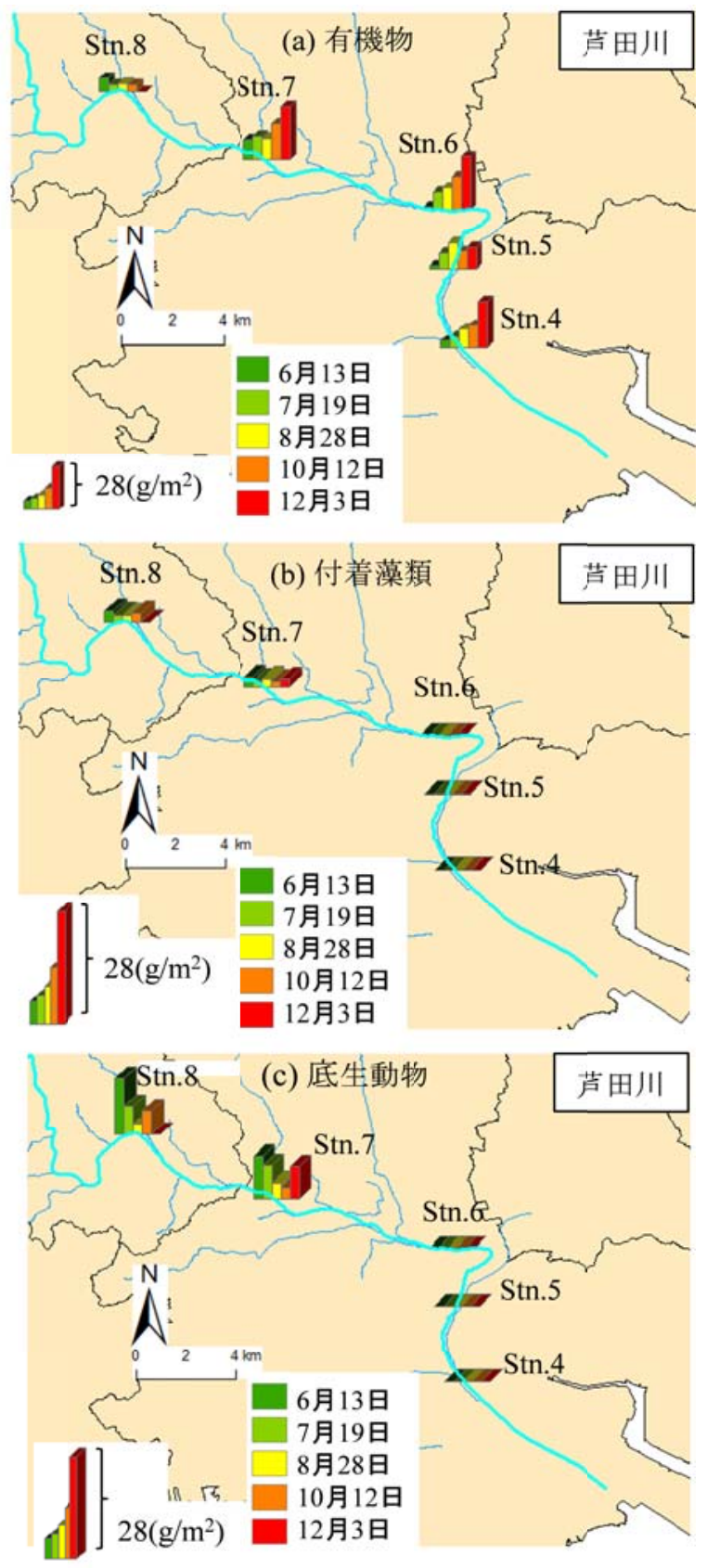

図-4 佐波川の Stn. 2 5 および芦田川の Stn. 4 8 の有機物量, 底生動物量, 付着藻類量の変化

はStn.2, 4において付着藻類および底生動物が多いことが わかる．付着藻類に関しては水温の高い7月25日〜11月5 日にかけて増加しており，底生動物に関しては羽化が始 まる前の4月18日が圧倒的に多い. 芦田川ではStn.4〜6に おいては全期間を通して，付着藻類と底生動物がほとん ど存在しなかった. 一方で，上流のStn.7，8では佐波川を 上回る底生動物量となっている.

\section{3. エクセルギ一効率による評価}

赤松・宮本》は生態系の健全性を評価する環境指標と
してエクセルギー効率を提案している.ここで，エクセ ルギーとはその環境の中で実際に使用可能な有効エネル ギーを意味する. 本研究で用いるエクセルギー効率 $\eta$ は, 系内に存在する有機物及び有機体の総エクセルギー（河 床堆積有機物 $E x_{d}$, 付着藻類 $E x_{a}$, 底生生物 $E x_{i}$, 魚類 $\left.E x_{f}\right)$ を系外から供給されるエクセルギー（出水によって系内 に供給されたエクセルギーEx $x_{i d}$, 出水後から定常状態に なるまでに供給された光エクセルギー $E x_{s}$ ) で除し以下の ように表わされる。

$$
\eta=\frac{E x_{d}+E x_{a}+E x_{i}+E x_{f}}{E x_{i d}+E x_{s}}
$$



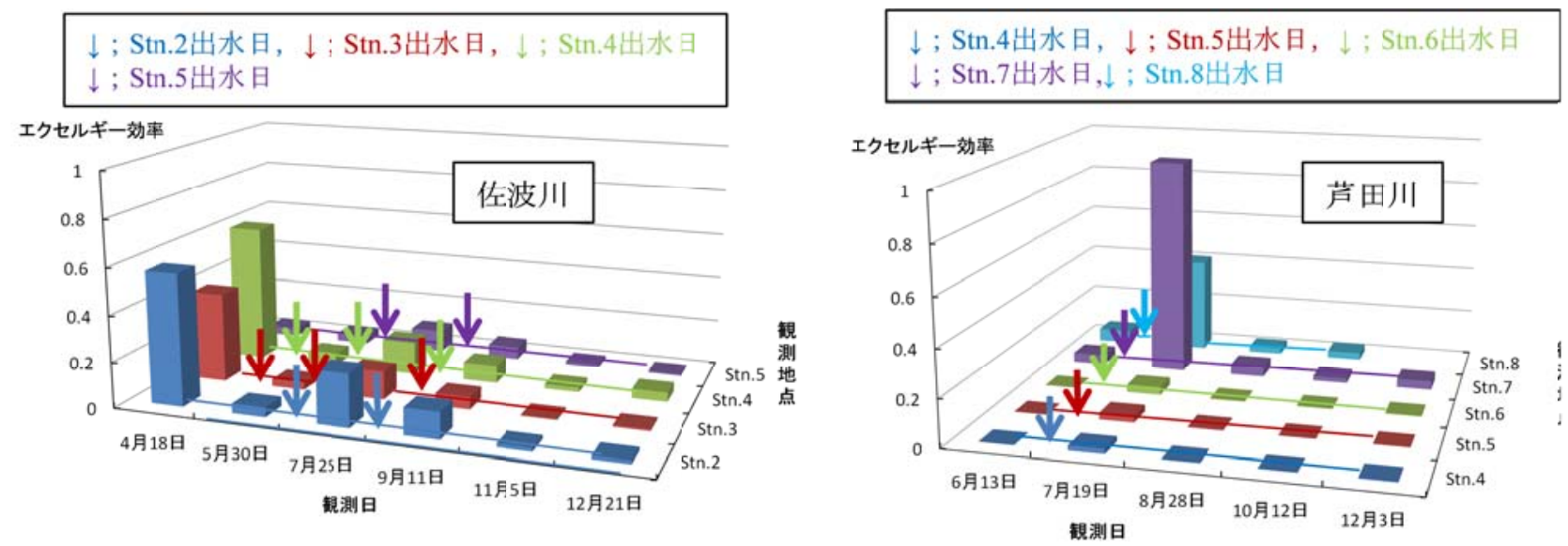

図-6＼cjkstart佐波川および芦田川の観測日のエクセルギ一効率

各エクセルギーの計算は赤松・宮本》に従った. エクセ ルギー効率 $\eta$ は，出水によって1に戻り時間の経過ととも に減少していく，この時，生態系の健全性が保たれてい る系では，供給されるエクセルギーが系内の生態系で効 率良く利用されるため, $\eta$ の減少が小さくなる。ここで の出水之は, 河床の付着藻類が十分に剥離する程度のも のとしている. 出水後の現地調査の結果から平均粒径の 磎が移動した場合には付着藻類が完全に剥離し, 河床が リセットされるものと考えた。平均粒径の限界摩擦速度

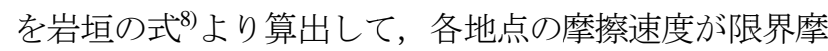
擦速度を超える流量を求めた．佐波川のStn.2には Stn.3 流量を, 芦田川のStn.4にはStn.5の流量を用いて，その他 の地点は図-2に示寸ハイドログラフを用いて検討した. その結果, 佐波川のリセットの起こる出水日は, Stn.2, Stn.5では4月11日，7月15日，8月14日，Stn.3では4月12日， 4月26日，7月17日，8月14日，Stn.4では4月11日，4月26 日，7月15日，8月14日である．また，芦田川のリセット の起こる出水日はStn.4〜7では7月15日，7月20日，11月 19日，Stn.8では7月8日，11月19日 であった。いずれの 河川においても, 出水からの経過日数が小さいほじ, 高 いエクセルギー効率をとっていることが分かる．佐波川 においては, 付着藻類および底生動物の現存量が多い Stn.2及びStn.4で高いエクセルギー効率をとることが分か る. 芦田川においては, 付着藻類および底生動物が存在 しないStn.4〜Stn.6で低い值を，それらが存在するStn.7, Stn.8では高い值を示している.

また，エクセルギー効率の連続的な推移を現地調査 結果およびエクセルギー効率の予測モデルを用いて算出 した ${ }^{6}$.このモデルでは地形データ，気象データ，日射 量・栄養塩・水温, 生物パラメーターを入力データとし て,「流域水物質循環モデル」,「藻類増殖モデル」, 「底 生動物成長モデル」の各要素モデルを用いて, 流量・水 深, 付着藻類量, 底生動物量を算出し, 式(1)を用いて エクセルギー効率を算出する. 図-7 に予測された佐波 川のエクセルギー効率の時系列変化を示寸. 出水の頻度
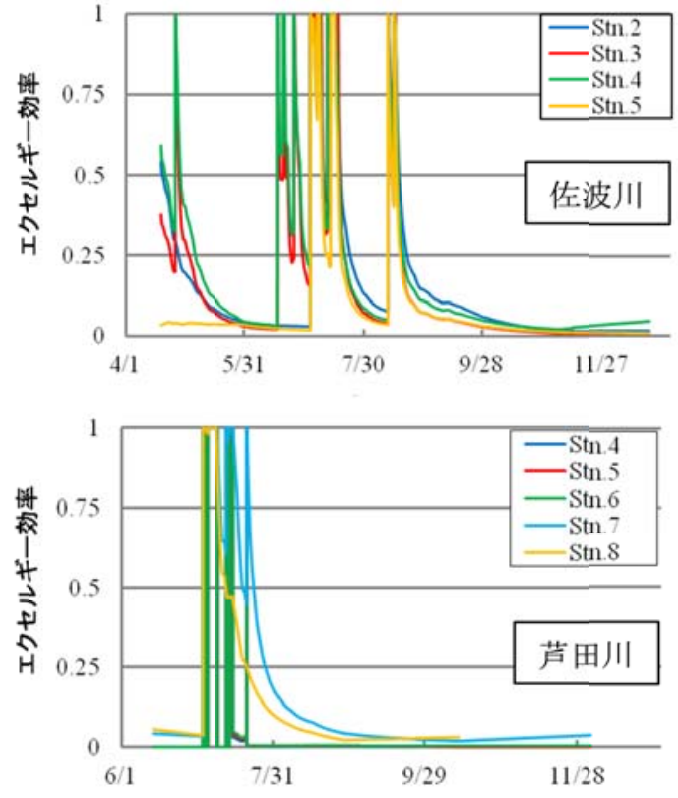

図-7 佐波川および芦田川のエクセルギ一効率の時系列変 化

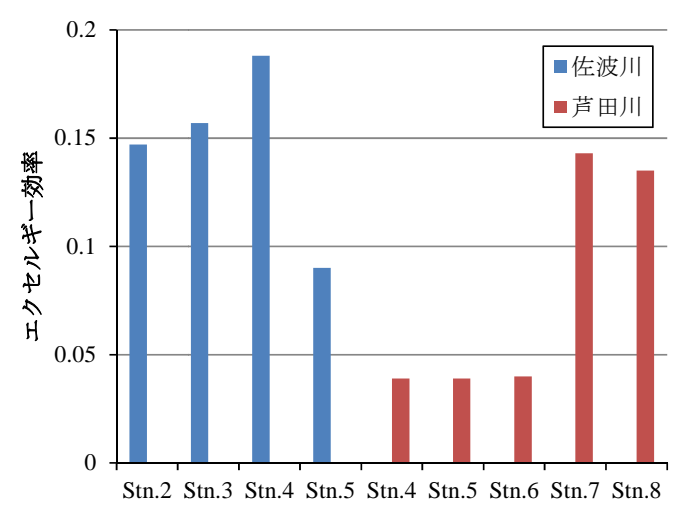

図-8＼cjkstart佐波川および芦田川の観測期間の平均エクセルギー 効率

が高い観測地点ではエクセルギー効率が高い值で推移し 

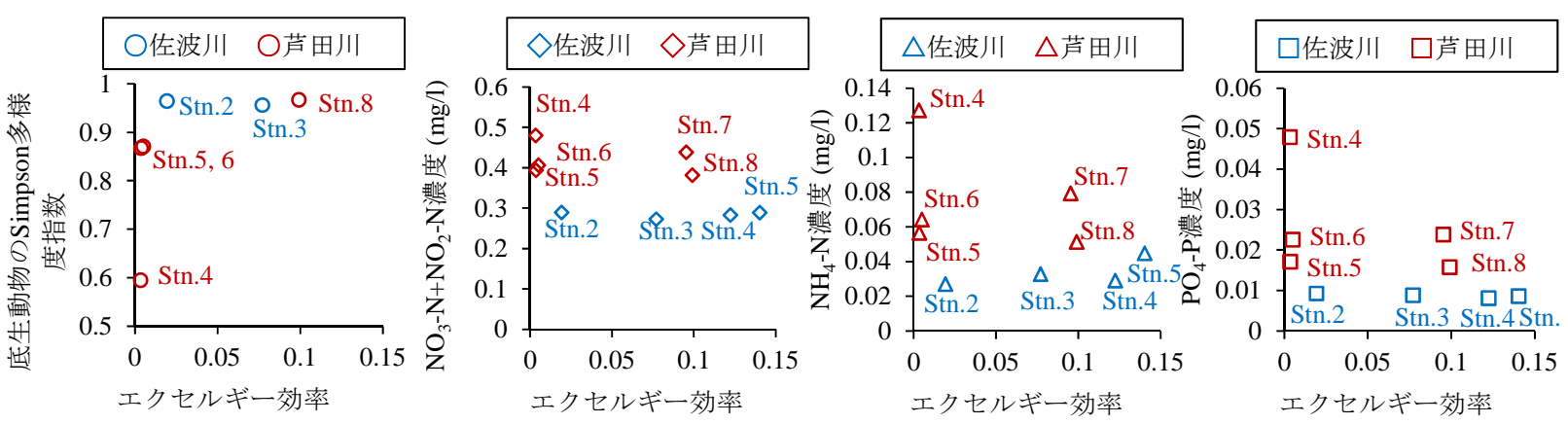

図-9 エクセルギ一効率と底生動物のSimpsonの多様度指数, 栄養塩濃度の比較

ている事が分かる。また，佐波川および芦田川の各観測 地点の観測期間の平均のエクセルギ一効率を図-8 に示 于.

\section{4. 河川生態環境評価法の比較}

佐波川および芦田川の各観測地点におけるエクセル ギー効率と底生動物のSimpsonの多様度指数9および $\mathrm{NO}_{3}$ $\mathrm{N}+\mathrm{NO}_{2}-\mathrm{N}, \quad \mathrm{NH}_{4}-\mathrm{N}, \mathrm{PO}_{4}-\mathrm{P}$ 濃度の比較を図-9に示す。な お，エクセルギー効率は図-8に示された平均值を， $\mathrm{NO}_{3}$ $\mathrm{N}+\mathrm{NO}_{2}-\mathrm{N}, \quad \mathrm{NH}_{4}-\mathrm{N}, \mathrm{PO}_{4}-\mathrm{P}$ 濃度は観測期間中の平均值を 用いた。底生動物のSimpson多様度指数は 国土交通省河 川水辺の国勢調査の4巡目（平成18～22年）の結果をも とに算出した。底生動物の多様性が低いところはエクセ ルギ一効率も低いといら関係性が見られる一方で， $\mathrm{NO}_{3}$ $\mathrm{N}+\mathrm{NO}_{2}-\mathrm{N}, \quad \mathrm{NH}_{4}-\mathrm{N}, \mathrm{PO}_{4}-\mathrm{P}$ 濃度とエクセルギー効率には 明確な関係性が見られない。芦田川の栄養塩濃度の高い 地点（Stn.7,8）においても，実際には付着藻類や底生動 物が佐波川に遜色ないほど存在し，その多様性も高かつ た。つまり，エクセルギ一効率による環境評価では生態 系に供給されたエネルギーが生態系上位の有機体（底生 動物や付着藻類）の成長に効率的に利用されるかどうか を評価するため，水質では評価しきれない生物の多様性 や健全性（ここではエクセルギ一効率自体の高さが健全 性を表すものと考えている）を評価可能であると考えら れる.

\section{5. 結論}

本研究では陸域負荷の異なる中国地方の佐波川および 芦田川において, 中流から下流の複数地点で水質, 生物 量の調査を行い, 各地点の河川生態環境を水質, エクセ ルギー効率といら観点から評価した。その結果，佐波川 および芦田川の複数地点間の生態系の健全性の違いを工
クセルギー効率で表現可能であることがわかった。 また， エクセルギー効率と水質および底生動物の多様度による 評価を比較したところ，エクセルギ一効率による環境評 価では水質では評価しきれない生物の多様性や健全性を 評価可能であることが示された.

謝辞 : 本研究は文部科学省科学研究費補助金挑戦的萌芽 (研究課題番号 : 25550093, 研究代表者 : 赤松良久) の 補助を受けている. また, 国土交通省受託研究「佐波川 の河床掘削・堰撤去が河川環境に与える影響の研究」の 一環として行われている. 記して謝意を表す。

\section{参考文献}

1）大垣眞一郎：河川と栄養塩類一管理に向けての提言一，技 報堂出版, 2005.

2）農林水産省 : 平成24年漁業・養殖業生産統計.

3) Karr, J. R.: Biological monitoring and environmental assessmenta conceptual framework, Environmental Management, Vol.11, pp.249-256, 1987.

4) Bovee, K. D.: A comprehensive overview of the Instream Flow Incremental Methodology, National Biological Service, Fort Collins, Colorado, 1995.

5）小出水規行, 松宮義晴 : Index of Biotic Integrityによる河川 魚類の生息環境評価, 水産海洋研究, Vol.61, pp.144-156, 1997.

6）赤松良久，笹川雄己，高村紀彰 : 有効エネルギー効率を用 いた佐波川の河川生態環境評価、土木学会論文集B1(水工 学), Vol.57, No.4, I_1261-I_1266, 2013.

7）赤松良久, 宮本大輔 : エクセルギー効率に基づく河川生 態環境評価法の開発, 水工学論文集, 第 52 巻, pp.11771182, 2008.

8）岩垣雄一：限界掃流力の流体力学的研究, 土木学会論文 集, Vol.41, pp.1-21, 1956.

9) Simpson E.H.: Measurement of diversity, nature, 163, pp.688, 1949.

(2013. 9. 30受付) 